Peran Tasawuf... Oleh: M. Arif Khoiruddin

\title{
PERAN TASAWUF DALAM KEHIDUPAN MASYARAKAT MODERN
}

\author{
Oleh: \\ M. Arif Khoiruddin
}

\section{Abstrak:}

Kehidupan masyarakat saat ini nampak tumbuh dan berkembang sifat-sifat materialistik dan hedonisme, gejala ini ditandai dengan menjadikan materi sebagai tolak ukur untuk mencapai kesuksesan dan kebahagian. Masyarakat berlomba-lomba mencari dan mendapatkan materi sebanyak-banyaknya. Dorongan seperti ini berdampak kecenderungan masyarakat bertindak tanpa kontrol demi mendapatkan apa yang diinginkan dengan menghalalkan segala cara tanpa memperdulikan sesama, hilangnya kepedulian sosial, kecenderungan individualistis, materialistis, kapitalis dan hedonis. Tasawuf dalam kehidupan sosial mempunyai pengaruh yang signifikan dalam menuntaskan permasalahan dan penyakit sosial yang ada, amalan yang terdapat dalam ajaran tasawuf akan membimbing seseorang dalam mengarungi kehidupan dunia menjadi manusia yang arif, bijaksana dan profesional dalam kehidupan bermasyarakat dan memberikan nilai-nilai spiritual dan sosial yang jelas. Bentuk ajaran yang ditawarkan untuk membersikan jiwa dan penyakit sosial tersebut dalam ajaran tasawuf dapat dilakukan dengan melalui tiga tahapan yaitu Takhalli membersihkan diri dari sifat-sifat tercela, dari maksiat lahir dan maksiat batin yang mengotori hati manusia seperti iri dan dengki, buruk sangka, sombong, membanggakan diri, pamer, pemarah dan sifat-sifat tercelah yang lain. Tahalli mensucikan atau menghiasi diri dengan sifat-sifat terpuji, dengan ta'at lahir dan taat batin. Tajalli terungkapnya nur ghaib untuk hati.

\footnotetext{
*IAIT Kediri
}

Volume 27 Nomor 1 Januari 2016 


\section{Kata Kunci: Tasawuf , Kehidupan Masyakat Modern}

\section{Pendahuluan}

Arus modernisasi dan globalisasi akan menciptakan sebuah sistem yang dapat melepas dan membebaskan manusia dari belenggu serta keterikatan terhadap ajaran agama, nilai-nilai spiritualitas, adat-istiadat dan sebagainya. Paradigma seperti ini manusia secara individual merasa berhak atas segalanya dan bebas menentukan nasibnya sendiri secara rasional tanpa ikatan agama maupun norma masyarakat.

Kehidupan yang semakin kompetitif dan daya saing semakin keras berdampak banyaknya manusia yang mengalami stress dan frustasi yang luar biasa. Masyarakat modern secara tidak langsung akan menganut dan mengikuti pola hidup materialistis, kapitalis, hedonis dan individualis. Untuk meminimalisir hal tersebut manusia perlu disirami dan disinari oleh nilai-nilai ajaran Islam yang penjabaran serta penerapannya terdapat dalam ajaran Tasawuf.

Kecenderungan manusia untuk mencari kembali nilainilai Ketuhanan merupakan bukti manusia pada dasarnya sebagai makhluk rohani dan makhluk jasmani. Sebagai makhluk jasmani manusia butuh sesuatu yang bersifat materi, namun sebagai makhluk rohani manusia membutuhkan sesuatu yang bersifat immateri atau rohani. Hal ini sesuai dengan orientasi ajaran dalam tasawuf yang lebih menekankan pada aspek rohani sesuai dengan fitrah manusia yang pada dasarnya cenderung bertasawuf. ${ }^{2}$

Manusia akan merasa kehilangan dan kekosongan rohani bila dalam hidupnya hanya mengandalkan ilmu materi saja tanpa mengimbanginya dengan ilmu agama. Hakikat jalan hidup manusia yang dijalani harus berlandaskan pada fitrahnya yaitu jalan menuju kehidupan serta kebahagiaan yang hakiki dengan landasan iman yang kokoh dan kuat, jiwa yang tenang dan

${ }^{1}$ M. Solihin dan M. Rosyid Anwar, Akhlak Tasawuf Manusia, Etika, dan Makna Hidup (Bandung: Nuansa, 2004), h. 16.

${ }^{2}$ Asmaran, Pengantar Studi Tasawuf (Jakarta: PT. Raja Grafindo Persada, 2012), h. 17. 
tentram, hidup yang aman menuju kebahagian dunia sampai akhirat.

Manusia sering kali dikendalikan oleh dorongan nafsu pribadi dan tidak dapat memegang kendali hawa nafsunya. Keadaan demikian akan mendorong manusia untuk berbuat sesuai dengan kenginannya tanpa memperhatikan orang lain, melakukan persaingan tidak sehat dengan menghalalkan berbagai cara, mencari kenikmatan dan kesenangan dunia dengan sebebas-bebasnya. Cara hidup yang demikian menurut Al-Ghazali akan membawa manusia pada kehancuran moral. ${ }^{3}$ Pandangan hidup tersebut akan menjurumuskan manusia kearah pertentangan dengan sesamanya sehingga dia melupakan hakikat dirinya sebagai hamba Allah yang harus berjalan sesuai aturan-aturan yang sudah ditetapkan-Nya.

Berbicara tentang nafsu pribadi, sebenarnya manusia tidak boleh mematikan sama sekali hawa nafsunya, tetapi harus menguasai agar nafsu tersebut tidak sampai menjerumuskan kepada kesesatan. Nafsu merupakan potensi yang diciptakan Tuhan dalam diri manusia agar dapat hidup lebih maju penuh kreativitas dan bersemangat. Memang nafsu manusia sebagaimana dijelaskan dalam Al-Qur'an mempunyai kecenderungan baik dan buruk. Nafsu akan menjadi baik bilamana dibersihkan dari sifat-sifat tercelah dengan cara menanamkan nilai-nilai dan ajaran agama sejak dini sehingga tabiat nafsu yang jahat itu dapat dikendalikan.

Proses pembersihan jiwa yang mengotori hati manusia dari sifat-sifat tercelah seperti rasa dengki (hasad), rasa sombong (takabbur), membanggakan diri (ujub), pamer (riya), pemarah (ghadab) dan sebagainya serta mensucikan dan menghiasi hati manusia dengan sifat-sifat terpuji seperti ikhlas, qona'ah, sabar, zuhud, sabar, tawadlu, waro' dan sifat-sifat terpuji lainnya merupakan salah satu bagian dari nilai-nilai ajaran tasawuf yang ditawarkan.

\title{
Pengertian Tasawuf
}

\author{
${ }^{3}$ Ibid., h. 67-68.
}

Volume 27 Nomor 1 Januari 2016 
Memahami dan menjelaskan pengertian tasawuf merupakan hal yang amat sulit, sedemikian besar dan luasnya sesuatu yang disebut tasawuf itu, sehingga seperti gambaran orang buta yang menjelaskan seekor gajah menurut bagian yang disentuhnya. Kemungkinan yang bisa dilakukan hanya memberi ciri-ciri yang menunjukkan pada istilah tersebut meskipun tidak utuh. Dalam ensiklopedi Islam ada beberapa pendapat para sufi tentang definisi tasawuf. Zakaria al-Anshari $(852-925 \mathrm{H})$ mendefinisikan tasawuf sebagai cara untuk mengajarkan bagaimana mensucikan diri, meningkatkan akhlak serta membangun kehidupan jasmani dan rohani untuk mencapai kehidupan hakiki. Sedangkan menurut al-Junaidi Al-Baghdadi (wafat $289 \mathrm{H}$ ) tasawuf adalah proses membersihkan hati dari sifat-sifat kemanusiaan (basyariyah), menjauhi hawa nafsu, memberikan tempat bagi sifat-sifat kerohanian, berpegang teguh pada ilmu kebenaran, mengamalkan sesuatu yang lebih utama berdasarkan keabadiannya, memberikan nasihat kepada sesama, benar-benar menepati janji kepada Allah SWT dan mengikuti syariat ajaran Rasulullah SAW.

Jadi unsur pokok serta utama dalam tasawuf adalah mensucikan diri dan tujuan akhirnya adalah kebahagiaan dan keselamatan abadi. Tetapi pada dasarnya tasawuf merupakan implementasi dari ihsan yang berarti beribadah kepada Allah seakan-akan melihat-Nya, apabila tidak mampu yang demikian, maka harus disadari bahwa Allah melihat diri kita, yang demikian itu adalah realitas penghayatan seseorang terhadap agamanya. Sebagaimana dalam hadits Shahih Muslim No. 09

$$
\text { أن تعبد الله كأتك تراه فإنك إن لا تراه فإنه يراك }
$$

Artinya: "Beribadahlah kalian kepada Allah seakan-akan melihat-Nya, jika kalian tidak bisa melihat-Nya, maka Ketahuilah bahwa Dia melihat kita".

Ihsan meliputi seluruh tingkah laku muslim baik tindakan lahir maupun tindakan batin, dalam ibadah (hubungan vertikal manusia dengan Tuhan) maupun muamalah (hubungan horizontal antara manusia dengan sesama manusia), sebab ihsan

${ }^{4}$ Dewan Redaksi, Ensiklopedi Islam (Jakarta: PT. Ichtiar Islam Baru van Houeve, 1994), h. 74. 
adalah jiwa atau roh dari iman dan Islam. Iman merupakan pondasi pada jiwa seseorang yang merupakan hasil perpaduan antara ilmu dan keyakinan, penjelmaannya berupa tindakan badaniah atau ibadah lahiriah yang disebut Islam. Perpaduan antara iman dan Islam pada diri seseorang akan tampak dalam pribadi dalam bentuk akhlak al-karimah atau disebut ihsan. ${ }^{5}$ Setidaknya tasawuf dapat memberi dorongan terdalam pada diri manusia yaitu berupa dorongan dalam mengaktualisasikan dirinya secara menyeluruh sebagai makhluk yang hakiki bersifat kerohanian dan kekal.

Beberapa uraian diatas dapat diambil pengertian yang sederhana bahwa tasawuf adalah proses latihan dengan cara riyadhah mujahadah (kesungguhan) untuk membersihkan, mempertinggi dan memperdalam kerohanian dalam rangka taqarrub kepada Allah. Tasawuf bagian ajaran Islam, karena tasawuf merupakan proses pendidikan akhlak manusia sebagaimana Islam diturunkan dalam rangka memperbaiki akhlak manusia agar tercapai kebahagiaan dan kesempurnaan lahir dan batin, baik dunia maupun akhirat.

\section{Tujuan Tasawuf}

Tasawuf sepenuhnya adalah disiplin ilmu yang berdasarkan ajaran Islam bertujuan untuk membentuk watak dan pribadi muslim menempuh insan kamil, dengan cara mengharuskan mereka melaksanakan sejumlah peraturan, tugas dan kewajiban serta keharusan lain. Dengan demikian dapatlah sekiranya dikatakan bahwa proses pembentukan insan kamil atau menjadi pribadi muslim yang menyadari sepenuhnya kedudukan dirinya dihadapan Allah SWT adalah merupakan tujuan utama dari tasawuf. Selain itu ditarik dari beberapa uraian pengertian tasawuf, maka dapat dijelaskan bahwa tujuan tasawuf adalah berusaha untuk melepaskan diri dari hawa nafsu dan keinginan yang dianggap menyimpang dari ajaran-ajaran agama dan berusaha untuk menyadari kehadiran-Nya.

\footnotetext{
${ }^{5}$ Muhammad Jamil, Cakrawala Tasawuf: Sejarah Pemikiran dan Kontekstualitas (Ciputat: GP Press, 2004), h. 55. 
Harun Nasution mengatakan dalam Islam Rasional bahwa tujuan seorang sufi adalah mendekatkan diri sedekat mungkin dengan Tuhan sampai ia dapat melihat Tuhan dengan mata hatinya bahkan bersatu dengan ruh Tuhan. Karena Tuhan adalah Maha Suci, Ia tidak dapat didekati kecuali oleh diri yang suci. Melalui sholat puasa dan ibadah-ibadah yang lain, seorang sufi melatih diri untuk menjadi bersih. Maka langkah pertama yang dilakukan oleh calon seorang sufi adalah membersihkan diri dari segala dosa dengan memperbanyak bertaubat. ${ }^{6}$

Dengan demikian, tasawuf bertujuan memberikan pemahaman untuk mati dalam diri kita dan hidup abadi dalam kehidupan untuk-Nya, membentuk akhlak yang mulia dengan memahami sepenuhnya atas posisi seorang hamba dihadapan Tuhan supaya hidup bahagia di dunia dan di akhirat atau menuju kebahagiaan yang abadi. Selain itu tasawuf bertujuan untuk memperoleh hubungan khusus dengan Tuhan. Kesadaran tersebut akan mengarah pada hubungan komunikasi antara Tuhan dengan makhluk-Nya.

\section{Peran Tasawuf dalam kehidupan modern}

Tasawuf dalam kehidupan sosial mempunyai pengaruh yang signifikan dalam menuntaskan permasalahan dan penyakit sosial yang ada, amalan yang terdapat dalam ajaran tasawuf akan membimbing seseorang dalam mengarungi kehidupan dunia menjadi manusia yang arif, bijaksana dan profesional dalam kehidupan bermasyarakat. Tasawuf sendiri selain memahami realitas lahiriyah juga mampu memahami realitas batiniyah sehingga seseorang mampu berinteraksi secara harmonis, serasi dan seimbang secara ubudiyah maupun muamalah berdasarkan nilai-nilai ajaran agama Islam.

Seseorang yang dikendalikan oleh nafsu pribadi dan bukan mengendalikan hawa nafsunya cenderung ingin melakukan hal-hal negatif seperti menghalalkan segala cara untuk mencapai tujuan dan kesenangan hidupnya, manusia seperti ini menurut Al-Ghazali akan membawa kejurang kehancuran moral. $^{7}$

\footnotetext{
${ }^{6}$ Harun Nasution, Islam Rasional (Bandung: Mizan, n.d.), h. 59.

${ }^{7}$ Asmaran, Pengantar Studi Tasawuf, h. 67.
} 
Menurut padangan kaum sufi bahwa rehabilitasi kondisi mental yang tidak baik adalah jika terapinya hanya didasarkan pada aspek lahiriyah saja, untuk itu pada tahap awal dalam tasawuf diharuskan melakukan amalan-amalan atau latihanlatihan rohani dengan tujuan untuk membersihkan jiwa dari nafsu yang tidak baik. Tingkah laku manusia yang dikendalikan oleh hawa nafsunya hanya berorientasi untuk kesenangan duniawi merupakan tabir yang menghalangi antara manusia dengan Allah. Untuk itu bentuk usaha yang dilakukan ahli tasawuf dalam membersihkan jiwa melalui tiga level (tingkatan) yakni: Takhalli, Tahalli dan Tajalli

\section{Takhalli}

Takhalli berarti membersihkan diri dari sifat-sifat tercela, dari maksiat lahir dan maksiat batin. Di antara sifat- sifat tercela yang mengotori jiwa (hati) manusia adalah dengki, buruk sangka, sombong, membanggakan diri, pamer, kikir dan sifatsifat tercelah yang lain. ${ }^{8}$

Firman Allah dalam Al-Qur'an surat Asy-Syams 91: 9

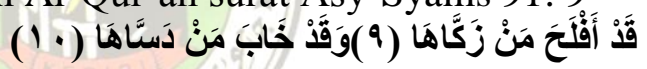

Terjemahnya: Sesungguhnya beruntunglah orang yang mensucikan jiwa itu. dan Sesungguhnya merugilah orang yang mengotorinya.

Pembicaraan tentang sikap atau kelakuan yang tercela ini dalam tasawuf atau akhlak lebih didahulukan daripada pembicaraaan tentang sikap atau kelakuan yang terpuji karena ia termasuk usaha takhliyah (mengosongkan diri dari sifat- sifat tercela) sambil mengisinya (tahliyah) dengan sifat- sifat yang terpuji.

Membersihkan diri dari sifat tercela menurut orang sufi dipandang penting karena sifat-sifat tersebut merupakan najis maknawi (najasah ma'nawiyah). Adanya najis-najis ini pada diri seseorang menyebabkan mustahil bisa dekat kepada Tuhan, seperti halnya mempunyai najis dzati (najash suriyah) ia tidak dapat melakukan ibadah yang diperintahkan Tuhan.

Maksiat lahir dan batin itulah yang mengotori jiwa manusia setiap waktu, terlebih maksiat batin yang merupakan

\footnotetext{
${ }^{8}$ Ibid., h. 67-68.
}

Volume 27 Nomor 1 Januari 2016 


\section{Peran Tasawuf... Oleh: M. Arif Khoiruddin}

bagian dari penyakit hati. Semua kotoran dan penyakit hati merupakan dinding-dinding tebal yang membatasi pada diri seseorang dengan Tuhan-Nya. Untuk itu kedua maksiat tersebut harus dibersihkan terlebih dahulu, yaitu membersikah diri dari sifat-sifat yang tercela agar dapat mengisi dengan sifat- sifat yang terpuji untuk memperoleh kebahagiaan hakiki.

Adapun sifat-sifat tercela atau penyakit hati yang perlu dibersihkan pada diri manusia sebagaimana diterangkan oleh HM. Amin Syukur sebagai berikut: ${ }^{10}$

\section{a. Hasad}

Hasad diartikan iri dan dengki. Hal ini terkandung pengertian adanya keinginan hilangnya suatu nikmat dari tangan orang lain, agar berpindah kepada dirinya.

Menurut Aboebakar Aceh hasad diartikan membenci nikmat Tuhan yang dianugerahkan kepada orang lain dengan keinginan agar nikmat orang lain itu terhapus. ${ }^{11}$ Hasad merupakan salah satu sifat jiwa yang keji, tidak dapat dihilangkan jika tidak memperoleh didikan dan latihan secara sufi.

\section{b. Al-Hirshu}

Al-Hirshu adalah suatu keinginan yang berlebih-lebihan terhadap masalah-masalah keduniaan. Sifat selalu ingin menang merupakan sifat kemanusiaan (manusiawi) dan sifat pembawaan manusia (al-Imran : 14).

Islam memandang keinginan yang berlebih-lebihan adalah dilarang, namun keinginan dalam batas kewajaran dan dalam rangka memenuhi kebutuhan primer seseorang, masih dalam batas diperbolehkan, karena ia merupakan sarana mempertahankan eksistensi di atas dunia ini, hanya saja cara dan materi pemenuhan keinginan (kebutuhan hidup) itu dalam kerangka norma dan kaidah yang berlaku. ${ }^{12}$

\section{c. Al-Takabburu}

Pelajar, 1996), h. 45-46.

${ }^{9}$ Zahri Mustofa, Ilmu Tasawuf (Surabaya: Bina Ilmu, 1976), h. 77.

${ }^{10}$ Amin Syukur, Pengantar Studi Islam (Yogyakarta: Pustaka

${ }^{11}$ Aboebakar Aceh, Pendidikan Sufi Sebuah Upaya Mendidik Akhlak Manusia (Solo: CV. Ramahani, n.d.), h. 31.

${ }^{12}$ Syukur, Pengantar Studi Islam, h. 229. 
Takabbur yang biasa diartikan kesombongan, berarti sikap dan sifat merendahkan orang lain dan bisa berarti menolak al-haq (kebenaran). Sebab-sebab yang menjadikan seseorang berlaku sombong (takabbur) ialah adanya perasaan kelebihan pada dirinya, seperti ilmu pengetahuan, amal ibadah, keturunan orang terhormat, harta kekayaan, kekuatan fisik, kedudukan, kecantikan, ketampanan dan sebagainya.

\section{d. Al-Ghadlab}

Ghadlab berarti marah. Sifat ini merupakan pembawaan setiap manusia, namun mereka berbeda dalam kadarnya, ada yang berdarah dingin, berdarah panas dan ada yang berdarah sedang. Bagi mereka yang berdarah dingin tidak mempunyai sifat marah, atau seandainya mempunyai, kadarnya hanya sedikit. Orang seperti ini dinilai tidak baik, karena justru manusia suatu ketika harus marah, manakala menyangkut hak asasinya yang harus dipertahankan. Imam Syafi'i pernah menyatakan, barang siapa yang semestinya harus marah, akan tetapi tidak mau marah, maka orang itu bagaikan himar. Sebaliknya bagi yang berdarah panas, sedikit tersinggung perasaannya, naik pitam, sehingga lupa daratan, keluar dari rel pemikiran yang sehat dan ketentuan agama bahkan seperti orang gila. Dalam hubungan ini menurut HM. Amin Syukur, yang paling baik ialah bersikap tengah di antara keduanya, yaitu marah untuk membela suatu kebenaran (haq), artinya marah yang proporsional.

\section{e. Riya' dan Sum'ah}

Riya' artinya mencari simpati dengan mempertahankan kebaikannya. Sifat ini dilarang oleh Allah (al-Ma'un : 4-6). Halhal atau kebaikan yang diperlihatkan ialah tubuh, perhiasan, ucapan, amalan lahir, pengikut atau teman dan sebagainya. Tanda-tanda orang yang riya' ialah malas beramal ketika berada dalam kesendirian dan giat apabila dilihat orang banyak, serta menambah amalnya ketika dipuji orang dan menguranginya ketika dicaci.

\section{f. Ujub atau $T a$ 'jub}

Ujub adalah mengherani diri sendiri atas kebaikan yang dilakukan dan kelebihan yang dimilikinya tanpa mengingat pemberi dan pendukungnya. Sifat ini mempunyai pengaruh 
negatif terhadap diri seseorang antara lain menjurus kepada sifat takabbur (sombong), lupa nikmat Allah dan dosanya, dan sebagainya. Oleh karena itu Allah mencelanya (at-Taubah : 25 dan al-Kahfi : 104).

\section{Tahalli}

Tahalli yakni mensucikan atau menghiasi diri dengan sifat-sifat terpuji, dengan ta'at lahir dan taat batin. ${ }^{13}$

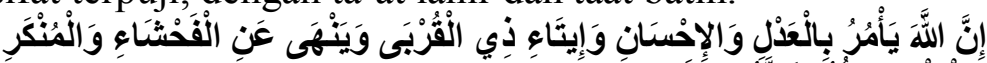

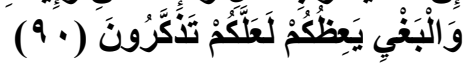

Terjemahnya: Sesungguhnya Allah menyuruh (kamu) Berlaku adil dan berbuat kebajikan, memberi kepada kaum kerabat, dan Allah melarang dari perbuatan keji, kemungkaran dan permusuhan. Dia memberi pengajaran kepadamu agar kamu dapat mengambil pelajaran.

Tahalli juga berarti menghiasi diri dengan jalan membiasakan diri dengan sifat, sikap serta perbuatan yang baik. Berusaha dalam setiap saat gerak perilaku selalu berjalan di atas ketentuan agama, baik kewajiban yang bersifat ketaatan lahir maupun yang bersifat batin. Yang dimaksud dengan ketaaatan lahir adalah kewajiban yang bersifat formal seperti melaksanakan salat, puasa ramadhan, mengeluarkan zakat, melaksanakan haji dan sebagainya. Sedangkan yang dimaksud dengan ketaatan batin adalah iman, ikhlas dan lain sebagainya. ${ }^{14}$

Tahalli yang dilakukan dengan cara menghiasi atau mengisi diri seseorang dengan sifat- sifat terpuji dengan taat sepenuhnya lahir dan batin. Pada tahap ini merupakan bagian dari pengisi jiwa yang telah dikosongkan dari sifat- sifat tercela. Dengan kata lain sesudah tahap pembersihan diri dari segala sifat tercela (takhalli) dapat dilalui kemudian usaha ini harus berlanjut ketahap berikutnya yaitu tahalli untuk memperoleh segala sifat terpuji. Diantaranya zuhud, qona'ah, sabar, tawakkal, mujahadah, ridha, syukur, ikhlas dan lainya.

\footnotetext{
${ }^{13}$ Asmaran, Pengantar Studi Tasawuf, h. 71.

${ }^{14}$ Ibid.
} 
Pengisian jiwa setelah kosongkan dari sifat-sifat buruk bukan berarti jiwa harus dikosongkan lebih dahulu baru kemudian diisi. Akan tetapi dengan cara pada saat menghilangkan kebiasaan yang buruk bersamaan dengan itu diisi dengan kebiasaan yang baik atau seperti halnya mengobati suatu penyakit pada diri seseorang bersamaan dengan obat yang masuk kedalam tubuhnya.

Imam Al-Ghazali menjelaskan bahwa bersifat baik atau berakhlak mulia artinya menghilangkan semua kebiasaan yang tercela yang telah dijelaskan oleh ajaran agama dan bersamaan dengan itu membiasakan sifat yang baik, mencintai dan melakukannya. Dalam bahasan lain sebagaimana Imam AlGhazali mengatakan yang dikatakan budi pekerti yang baik ialah membuat kerelaan seluruh makhluk, baik dalam keadaan lapang maupun susah.

Di dalam kitabnya Al-Arba'in, Al-Ghazali mengatakan bahwa yang dimaksud dengan budi pekerti baik ialah bersifat tidak kikir dan tidak boros, tetapi diantara keduanya. Atau dengan kata lain, sifat yang baik itu adalah bersikap moderat di antara dua yang eksterm. Sebenarnya dari beberapa penjelasan yang ada pada dasarnya perbuatan baik, budi pekerti yang baik atau akhlak terpuji itu ialah sifat- sifat atau tingkah laku yang sesuai dengan norma-norma ajaran agama (Islam).

Untuk merehabilitis sikap mental yang tidak baik, menurut orang sufi tidak akan berhasil apabila terapinya hanya dari aspek lahiriah saja. Makanya pada tahap-tahap awal memasuki kehidupan tasawuf seorang murid diharuskan melakukan amalan dan latihan kerohanian yang cukup berat. Tujuannya adalah untuk menguasai hawa nafsu, menekanya sampai ke titik terendah; atau apabila mungkin mematikan sama sekali. Jiwa manusia, kata Al-Ghazali dapat dilatih, dikuasai, diubah dan dapat dibentuk sesuai dengan kehendak manusia itu sendiri. Dari satu latihan akan menjadi kebiasaaan dan dari kebiasaan akan menghasilkan kepribadian. ${ }^{15}$

Menurut Al Ghazali, jiwa manusia dapat diubah, dilatih, dikuasai, dan dibentuk sesuai dengan kehendak manusia itu

${ }^{15}$ Ibid., h. 73.

Volume 27 Nomor 1 Januari 2016 
sendiri. Perbuatan baik yang sangat penting di isikan kedalam jiwa manusia dan dibiasakan dalam perbuatan agar menjadi manusia paripurna (insane kamil). Perbuatan baik itu, antara lain sebagai berikut: ${ }^{16}$

a. Taubat

Mayoritas para sufi menjadikan taubat sebagai perhentian awal dijalan menuju Allah. Pada tingkatan terendah, taubat menyangkut dosa yang dilakukan anggota badan. Pada tingkat menengah, taubat menyangkut pangkal dosa-dosa, seperti dengki, sombong, dan ria. Pada tingkat yang lebih tinggi, tobat menyangkut usaha menjauhkan bujukan setan dan menyadarkan jiwa akan rasa bersalah. Pada tingkat terakhir, taubat berarti penyesalan atas kelengahan pikiran dalam mengingat Allah. Taubat pada tingkat ini adalah penolakan terhadap segala sesuatu yang dapat memalingkan dari jalan Allah.

Al Ghazali mengklasifikasikan taubat menjadi tiga tingkatan yaitu:

1. Meninggalkan kejahatan dalam segala bentuknya dan beralih pada kebaikan karena takut terhadap siksa Allah.

2. Beralih dari satu situasi yang sudah baik menuju situasi yang lebih baik lagi. Dalam tasawuf keadaan ini sering disebut dengan inabah

3. Rasa penyesalan yang dilakukan semata mata karena ketaatan dan kecintaan kepada Allah hal ini disebut aubah

b. Khauf dan Raja'

Bagi kalangan sufi khauf dan raja' berjalan seimbang dan saling mempengaruhi. Khauf adalah perasaan takut seorang hamba semata mata kepada Allah, sedangkan Raja' adalah perasaan hati yang senang karena menati sesuatu yang diinginkan dan disenangi.

Menurut Al-Ghazali, Raja' adalah rasa lapang hati dalam menantikan hal yang diharapkan pada masa yang akan datang yang mungkin terjadi. Raja' merupakan sikap hidup yang selalu

\footnotetext{
${ }^{16}$ Samsul Munir Amin, Ilmu Tasawuf (Jakarta: Hamzah, 2012), h. 214-220. 124

Volume 27 Nomor 1 Januari 2016
} 
mendorong seseorang untuk lebih banyak berbuat dan beramal shaleh sehingga menjadi taat kepada Allah dan Rasul-Nya.

Biasanya orang yang memiliki sikap Raja' juga memiliki sikap Khauf. Khauf dan raja' saling berhubungan, kekurangan Khauf akan menyebabkan seseorang lalai daan berani berbuat maksiat, sedangkan Khauf yang berlebihan akan menjadikan seseorang menjadi putus asa dan pesimistis. Keseimbangan antara Khauf dan Raja' sama sama penting karena tanpa Raja', orang akan serba khawatir, tidak mempunyai gairah hidup, serba takut, dan pesimistis. Dimilikinya Khauf dalam kadar sedang akan membuat orang senatiasa waspada dan hati hati dalam berperilaku agar terhindar dari ancaman.

Dengan dmikian dua sikap tersebut merupakan sikap mental yang bersifat introspeksi, mawas diri, dan selalu memikirkan kehidupan yang akan datang, yaitu kehidupan abadi di alam akhirat.

c. Zuhud

Zuhud yaitu ketidak tertarikan pada dunia atau harta benda. Zuhud terbagi menjadi tiga tingkatan yaitu:

1. Zuhud yang terendah adalah menjauhkan diri dari dunia ini agar terhindar dari hukuman di akhirat.

2. Menjauhi dunia dengan menimbang imbalan akhirat

3. Merupakan maqam tertinggi adalah mengucilkan dunia bukan karena takut atau karena berharap, tetapi karena cinta kepada Allah.

Orang yang berada pada tingkat tertinggi ini akan memandang segala sesuatu, kecuali Allah, tidak mempunyai arti apa apa. Sesuai dengan pandangan sufi, hawa nafsu duniwilah yang menjadi sumber kerusakan moral manusia. Sikap kecenderungan seseorang kepada hawa nafsu, mengakibatkan kebrutalan dalam mengejar kepuasan nafsunya. Dorongan jiwa yang ingin menikmati kehidupan dunia akan menimbulkan kesenjangan antar manusia dengan Allah.

Al Ghazali mengartikan zuhud sebagai sikap mengurangi keterikatan kepada dunia untuk kemudian menjauhinya dengan penuh kesadaran. Al Qusyairi mengartikan zuhud sebagai suatu sikap menerima rezeki yang diperolehnya. Jika kaya, ia tidak 
merasa bangga dan gembira. Sebaliknya, jika miskin iapun tidak bersedih.

Hasan Al Bashri mengatakan bahwa Zuhud itu meninggalkan kehidupan dunia kerena dunia itu seperti ular, licin jika dipegang tetapi racunnya dapat membunuh. Inti dan tujuan zuhud sama, yaitu tidak menjadikan kehidupan dunia sebagai tujuan akhir.

d. Fakir

Fakir bermakna tidak menuntut lebih banyak dan merasa puas dengan apa yang sudah dimiliki sehingga tidak meminta sesuatu yang lain. Sikap mental fakir merupakan benteng pertahana yang kuat dalam menghadapi pengaruh dalam menghadapi kehidupan materi. Hal ini karena sikap fakir dapat menghindarkan seseorang dari semua keserakahan. Dengan demikian, pada prinsipnya sikap mental fakir merupakan rentetan sikap zuhud. Hanya saja, zuhud lebih keras menghadapi kehidupan duniawi, sedangkan fakir hanya sekadar pendisiplinan diri dalam memanfaatkan fasilitas hidup. Sikap fakir dapat memunuculkan sikap wara', yaitu sikap berhati hati dalam menghadapi segala sesuatu yang kurang jelas masalahnya. Apabila bertemu dengan satu persoalan baik yang bersifat materi maupun non materi yang tidak pasti hukumnya lebih baik dihindari.

e. Sabar

Menurut Al Ghazali sabar adalah suatu kondisi jiwa yang terjadi karena adanya dorongan ajaran agama dalam mengendalikan hawa nafsu. Dengan demikian, sabar berarti konsisten dalam melaksanakan semua perintah Allah, menghadapi kesulitan, dan tabah dalam menghadapi cobaan selama dalam perjuangan untuk mencapai tujuan. Oleh karena itu, sabar erat hubungannya dengan pengendalian diri, sikap dan emosi. Apabila seseorang telah mapu mengendalikan nafsunya, maka sikap sabar akan tercipta.

Tercapainya karakter sabar merupakan respon dari keyakinan yang dipertahankan. Keyakinan adalah landasan sabar, apabila seseorang telah yakin bahwa jalan yang ditempuhnya benar, maka ia akan teguh dalam pendiriannya walaupun menghadapi tantangan. 
Al Ghazali membedakan tingkatan sabar, menjadi iffah, hilm, qana'ah dan syaja'ah. Iffah ialah kemampuan mengatasi hawa nafsu. Hilm merupakan kesanggupan seseorang menguasai diri agar tidak marah. Qana'ah yaitu ketabahan hati untuk meneriman nasib. Adapun syaja'ah yaitu sifat pantang menyerah. $^{17}$

\section{f. Ridha}

Pengertian ridha adalah menerima hal-hal yang tidak menyenangkan. Seorang dengan senang hati menerima ketentuan atau qodho dari Allah dan tidak mengingkari apa yang telah menjadi keputusan-Nya. Sikap mental ridha merupakan perpaduan dari mahabbah dan sabar. Rasa cinta yang diperkuat dengan ketabahan akan menimbulkan kelapangan hati untuk berkorban demi yang dicintai. Seorang hamba yang ridha, ia rela menuruti apa yang dikehendaki Allah dengan senang hati, sekaligus tidak dibarengi sikap menentang dan menyesal.

\section{g. Muraqabah}

Muraqabah berarti mawas diri. Muraqabah mempunyai makna hampir sama dengan introspeksi. Dengan kata lain muraqabah adalah siap dan siaga setiap saat untuk meneliti keadaan sendiri. Seorang sufi sejak awal sudah diajarkan bahwa dirinya tidak pernah lepas dari pengawasan Allah. Seluruh aktifitas hidupnya ditujukan untuk berada sedekat mungkin dengan-Nya. Ia sadar bahwa Allah melihatnya. Kesadaran itu membawanya pada satu sikap mawas diri atau muraqabah

\section{Tajalli}

Untuk pemantapan dan pendalaman materi yang telah dilalui pada fase tahalli, maka rangkaian pendidikan mental itu disempurnakan pada fase tajalli. Tajalli berarti terungkapnya nur ghaib untuk hati. ${ }^{19}$

Dalam hal ini kaum sufi mendasarkan pandapatnya pada

\footnotetext{
${ }^{17}$ Abdul Mustaqim, Akhlak tasawuf (Yogyakarta: Kreasi Wacana, 2007), h. 95.

${ }^{18}$ Ibid.

${ }^{19}$ Ibid.
}

Volume 27 Nomor 1 Januari 2016 
Firman Allah dalam Al Qur'an surat An- Nur: 35

Terjemahnya: Allah (Pemberi) cahaya (kepada) langit dan bumi.

Tajalli ialah lenyap atau hilangnya hijab dari sifat- sifat kebasyariahan (kemanusiaan), jelasnya nur yang selama itu ghaib, fananya atau lenyapnya segala yang lain ketika nampaknya wajah Allah. ${ }^{20}$

Berdasarkan ayat Al-Qur'an diatas, kaum sufi yakin bahwa seseorang dapat memperoleh pancaran nur llahi. Demikian Allah tampak dengan af'al, amsa', sifat dan zatNya. Mustahil orang dapat menutupi cahaya, sedang cahaya itu terpancar dalam segala yang tertutup. Apalagi Allah adalah cahaya langit dan bumi.

Imam Al-Ghazali pernah mengatakan bahwa: "tersingkapnya hal- hal yang ghaib yang menjadi pengetahuan kita yang hakiki karena nur yang dipancarkan Allah ke dalam dada (hati) seseorang".

\section{Penutup}

Relefansi nilai-nilai yang terdapat dalam ajaran tasawuf memiliki peran penting dalam kehidupan sosial masyarakat modern. Ajaran tasawuf sebagaimana diatas jika diterapkan akan memberikan makna hidup manusia dalam membentuk kondisi lingkungan yang kondusif dan berakhlak. Konsep tahalli yakni membersihkan diri dari sifat tercelah (akhlak madzmumah) adalah solusi dalam mengatasi penyakit-penyakit sosial dalam masyarakat. Konsep tahalli yakni mensucikan atau menghiasi diri seseorang dengan sifat-sifat terpuji seperti sabar, zuhud, ikhlas dan sifat-sifat terpuji lainnya akan memberikan ketenangan dan ketentraman hidup manusia dan terhindar dari sifat materialistik, individualistik, gejaja stress maupun frustasi.

${ }^{20}$ Ibid., h. 74. 
Peran Tasawuf... Oleh: M. Arif Khoiruddin

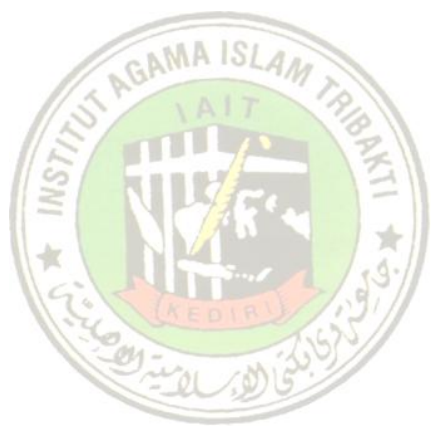




\section{DAFTAR PUSTAKA}

Aceh, Aboebakar. Pendidikan Sufi Sebuah Upaya Mendidik Akhlak Manusia. Solo: CV. Ramahani, n.d.

Amin, Samsul Munir. Ilmu Tasawuf. Jakarta: Hamzah, 2012.

Asmaran. Pengantar Studi Tasawuf. Jakarta: PT. Raja Grafindo Persada, 2012.

Jamil, Muhammad. Cakrawala Tasawuf: Sejarah Pemikiran dan Kontekstualitas. Ciputat: GP Press, 2004.

Mustaqim, Abdul. Akhlak tasawuf. Yogyakarta: Kreasi Wacana, 2007.

Mustofa, Zahri. Ilmu Tasawuf. Surabaya: Bina Ilmu, 1976.

Nasution, Harun. Islam Rasional. Bandung: Mizan, 1995.

Redaksi, Dewan. Ensiklopedi Islam. Jakarta: PT. Ichtiar Islam Baru van Houeve, 1994.

Solihin, M., dan M. Rosyid Anwar. Akhlak Tasawuf Manusia, Etika, dan Makna Hidup. Bandung: Nuansa, 2004.

Syukur, Amin. Pengantar Studi Islam. Yogyakarta: Pustaka Pelajar, 1996. 